\title{
Pre-service and in-service teachers'
} perceptions on the integration of children's literature in mathematics teaching and learning in Ireland

Article

Accepted Version

Prendergast, M., Harbison, L., Miller, S. and Trakulphadetkrai, N. V. (2019) Pre-service and in-service teachers' perceptions on the integration of children's literature in mathematics teaching and learning in Ireland. Irish Educational Studies, 38 (2). pp. 157-175. ISSN 0332-3315 doi:

https://doi.org/10.1080/03323315.2018.1484302 Available at https://centaur.reading.ac.uk/78537/

It is advisable to refer to the publisher's version if you intend to cite from the work. See Guidance on citing.

To link to this article DOI: http://dx.doi.org/10.1080/03323315.2018.1484302

Publisher: Taylor \& Francis

All outputs in CentAUR are protected by Intellectual Property Rights law, including copyright law. Copyright and IPR is retained by the creators or other copyright holders. Terms and conditions for use of this material are defined in the End User Agreement. 


\section{www.reading.ac.uk/centaur}

\section{CentAUR}

Central Archive at the University of Reading

Reading's research outputs online 


\section{Pre-Service and In-Service Teachers' Perceptions on the Integration of Children's Literature in Mathematics Teaching and Learning in Ireland}

Mark Prendergast ${ }^{\mathrm{a} *}$, Lorraine Harbison ${ }^{\mathrm{b}}$, Sue Miller ${ }^{\mathrm{c}}$ and Natthapoj

Vincent Trakulphadetkrai ${ }^{\mathrm{d}}$

${ }^{a}$ School of Education, Trinity College Dublin, University of Dublin, Dublin 2, Ireland;

${ }^{b}$ School of STEM Education, Innovation \& Global Studies, Dublin City University, Ireland;

'Institute of Education, Dublin City University, Ireland;

${ }^{d}$ Institute of Education, University of Reading, 4 Redlands Road, Reading, UK.

Corresponding Author: Mark Prendergast*

E-mail: mark.prendergast@tcd.ie

Tel: $+353(0) 18964855$ 


\section{Pre-Service and In-Service Teachers' Perceptions on the Integration of Children's Literature in Mathematics Teaching and Learning in Ireland}

The beneficial role that children's literature plays in facilitating the meaningful integration and advancement of literacy and numeracy in the primary mathematics classroom has been well validated by research findings internationally. In Ireland, supporting the development of literacy and numeracy is a key educational priority. Consequently, a myriad of policy initiatives such as the Literacy and Numeracy for Learning and Life strategy have been introduced. All aim to address concerns about young people's lack of basic literacy and numeracy skills and to consider new teaching and learning modalities to enhance same. Despite this, no official emphasis is given to incorporating literature in the Irish primary school mathematics curriculum. Therefore, it is pertinent and timely that this study seeks to ascertain pre-service and in-service teachers' views on the use of literature to support mathematics teaching and learning and to investigate perceived barriers to and enablers for the integration of children' literature in the mathematics classroom in Ireland. The analysis of the findings will be framed using Ajzen (1991)'s Theory of Planned Behavior (TPB) model. This research is part of a large international research collaboration (see www.mathsthroughstories.org), in which the beliefs of teachers with respect to children's literature are investigated.

Keywords: Children's literature; barriers and enablers; mathematics learning and teaching; teachers' beliefs; mathematics teacher education

\section{Introduction}

The role of children's literature in facilitating meaningful integration of literacy and numeracy in the primary mathematics classroom has been the focus of much research over the past forty years (Whitin 1992; Jennings et al. 1992; Moyer 2000; Shatzer 2008; Whittin and Wilde 1992). Findings suggest that, "Experiences with mathematicallyrelated stories have the potential to promote aspects of mathematical proficiency, including procedural fluency, adaptive reasoning and a productive disposition" (NCCA 
2014, 53). For example in the U.S. Cotti and Schiro (2004) determine that the use of children's literature by both pre-service and experienced early childhood and primary teachers is one of the most powerful tools available to help in teaching mathematics.

However, despite potential pedagogical benefits, whether or not this approach is adopted largely depends on several key factors (Ajzen 1991). One of these factors is teachers' willingness to incorporate literature given the fact that there is no statutory requirement to do so. This study will endeavour to investigate other perceived barriers to and enablers for the integration of children's literature in mathematics teaching and learning as expressed by a sample of pre-service and in-service primary school teachers in Ireland. A review of literature will contextualise the rationale for integrating literacy in the mathematics classroom followed by a more specific focus on issues regarding the use of children's literature and mathematics.

\section{Literature Review}

\section{Integrating literacy in mathematics}

In 2011, Ireland's Department of Education and Skills (DES) launched a national strategy 'Literacy and Numeracy for Learning and Life' with the aim of improving literacy and numeracy standards among children and young people. The strategy was published in response to repeated concerns raised regarding the lack of young people's basic literacy and numeracy skills "to cope with every-day life" (DES 2011, 13). In light of such concerns, the Strategy set targets for improving literacy and numeracy standards to be achieved by the year 2020 and recommended the integration of literacy and numeracy skills in other areas of the curriculum (DES 2011, 46). Research from an international perspective supports this more integrated approach (Trakulphadetkrai et al. 2017). Bintz et al. (2011) determine that a school day will never have enough hours to 
teach both literacy and numeracy adequately and thoroughly. However, by creating connections between the two, there is ample opportunity to develop both areas (Altieri 2010).

Before this can happen, there must be a realisation that all subjects are rooted in literacy and numeracy, not just the obvious ones. For example, although numeracy is firmly embedded in the mathematics curriculum, it should not be left solely for the mathematics teacher to promote (Liljedahl 2015). The same can be said for literacy and English. An evaluation of the Irish Primary School Curriculum revealed that its integrated nature needs to be further exemplified for teachers so as to "support the development of children's English language skills throughout the day, in all curriculum subjects, rather than in a discrete manner through English alone" (NCCA 2005, 10).

There are some examples of such an integrated approach being recognised in policy, for example integrating literacy in mathematic. In the U.S., the Principles and Standards for School Mathematics (NCTM 2000) recommend that students spend more time reading, writing, and discussing ideas. Furthermore, the National Council of Teachers of Mathematics along with the International Reading Association (IRA) and the National Council of Teachers of English (NCTE) all call for the integration of subject areas through literacy (Wilburne and Napoli 2008).

Thus while the importance of integrating literacy in subjects such as mathematics may be recognised, more strategies must be put in place to help individual teachers realise this goal.

\section{Children's literature and mathematics}

One strategy for integrating literacy and mathematics is through the incorporation of children's literature. This idea has been promoted since the 1970s (Whittin and Wilde 
1992) with a body of published works providing many insights over the years. Casey et al. (2008), for example, argue that knowledge can be understood more effectively when it is taught within a story context, rather than in a de-contextualized format. Thus, taking mathematical concepts and recasting them into narratives can be a powerful means of communicating and retaining mathematical knowledge (Moyer 2000). This is important as children are often unable to recognise the usefulness of mathematics in their own lives (Kurz and Bartholomew 2012). However, Whittin and Wilde (1992) note that children's literature can provide a meaningful context for learning. Abstract mathematical concepts are embedded in informal meaningful real-world contexts that children can relate to and better comprehend. This view is supported by a range of empirical studies, for example, those conducted by McAndrew, Morris, and Fennell (2017), Jennings et al. (1992) and Van den Heuvel-Panhuizen and Elia (2011), all of which have found that children's mathematical ability increased when mathematics was taught together with literature.

\section{Issues regarding the use of children's literature in the mathematics classroom}

Despite such advantages and the fact that the use of children's literature as a springboard for mathematics ideas has been promoted since the 1970s, classroom practice has not always reflected this integration (Moyer 2000). This is notwithstanding that many children's difficulties with mathematics stem from language and literacy issues (KrickMorales 2006). Furthermore, the foundations of language and mathematical ideas are developed at primary school level and the connections teachers can make during this time are critical to children's development (Moyer 2000).

However, any type of educational change is a complex process and there are many associated challenges (Handal and Herrington 2003). One of these challenges is convincing teachers of merits in implementing initiatives that they have not previously 
used (Prendergast and Treacy 2017). As far back as 1975, Lortie noted that teachers are often reluctant to adopt new practices such as integrating children's literature, unless they feel sure they can make them work. This means that teacher's beliefs and personal theories about teaching influence how they value and implement any changes in their classrooms (Manouchehri and Goodman 1998). Thus, it is important for policy-makers and educators to have an understanding of teachers' perceived barriers and enablers towards a specific educational change if successful implementation is to take place.

\section{Theoretical Background}

In exploring the issue of teachers' perceived barriers and enablers towards integrating children's literature in the classroom, the authors decided upon the use of Ajzen (1991)'s Theory of Planned Behavior (TPB) as an underpinning theoretical framework. The use of any new resource in the classroom requires a marked change in behaviour for practicing mathematics teachers who have become accustomed to a particular way of teaching (Pierce and Ball 2009). Ajzen (1991) put forward the TPB to focus on the factors affecting a person's intention to change. The TPB considers beliefs that may either enable or present barriers, to a person's intention to change.

According to the TPB, there are three main types of beliefs each of which can be directly related to teachers' perceived enablers and barriers. The first kind of belief, Attitude toward the behaviour, is personal in nature and is "the degree to which a person has a favourable or unfavourable evaluation or appraisal of the behaviour in question" (Ajzen 1991, 118). Research suggests that each teacher holds a particular belief system comprising a wide range of beliefs about the education system, the curriculum and their own teaching (Handal and Herrington 2003). These beliefs act as a filter through which teachers make their decisions (Wittrock, Clark, and Peterson 1990). The second kind of 
belief, is a social factor termed Subjective norm; it refers to the "perceived social pressure to perform or not to perform the behaviour" (Ajzen 1991, 118). For example, would others approve or disapprove of their integrating children's literature and would those people themselves engage, or otherwise, in its adoption (Underwood 2012). The third kind of belief of the TPB is the degree of Perceived behavioural control which refers to the "perceived ease or difficulty of performing the behaviour and it is assumed to reflect past experience as well as anticipated impediments and obstacles" (Ajzen 1991, 118).

Many teachers' beliefs were developed when they themselves were students during what Lortie $(1975,61)$ referred to as "the apprenticeship of observation". However, for the most part, these observations would have taken place in traditional mathematics classrooms, which by their very nature, often conflict with educational innovations such as the integration of children's literature. Consequently, initial teacher education (ITE) programmes struggle to produce teachers with beliefs consistent with curriculum innovation and best practice (Kennedy 1991). Wilburne and Napoli (2008) acknowledge this difficulty and determine that ITE providers should offer literature-based mathematics experiences to help pre-service teachers interrogate their beliefs about effective ways to teach the subject. Such opportunities should also be extended to inservice teachers through a mechanism of continuous professional development (CPD). Thus, the integration of children's literature in the mathematics classroom offers an opportunity to challenge pre-service and in-service teachers pre-defined views of teaching by exposing them to an alternative approach that differs from the "frontal teaching" approach (Feiman-Nemser 1989) that they themselves may have encountered during their previous education.

The application of TPB in the context of this study is not expected to reveal new 
factors affecting teachers' integration of children's literature for teaching mathematics. However, as determined by Pierce and Ball (2009), its use as a theoretical framework can act as an organiser that draws attention to the perceived enablers and barriers to teachers adopting this practice. This will inform best practise for those in ITE and also for CPD with in-service teachers. With such an aim in mind, this study thus seeks to address the following research question: What do primary school teachers in Ireland perceive to be key barriers to and enablers for the integration of children's literature in mathematics teaching and learning?

\section{Methods}

\section{Sample}

A purposive, non-probability sampling strategy was selected for this study. In order to obtain a high response rate, a link to the questionnaire along with a short blurb was made available through a number of on-line and printed teacher magazines, forum, and educational websites. This ensured a wide-ranging demographic of both in-service and pre-service participants from around the country. This sampling strategy means that it is impossible to indicate a response rate. In total, 154 survey participants responded, including 51 in-service teachers and 103 pre-service teachers. Characteristics of the survey participants are reported in Table 1. Overall, a convenient but fairly representative sample of teachers was obtained.

\section{Data Collection}

The data was collected via an on-line open-ended questionnaire. The questionnaire contained four key sections: the first section asked the participants to define and give examples of children's literature; the second section asked the participants to write the 
first five thoughts that come to their mind when they think about the 'the integration of children's literature in mathematics teaching and learning'; the third section contained eight questions relating to their experience (if any) of implementing this integrative approach; and the fourth and final section asked contextual information about the participants.

The data reported in this paper were drawn from the participants' responses to the two following questions in the third section of the questionnaire: 1) 'In your experience, what are the key barriers that stop you from incorporating (more) children's literature in your mathematics teaching?' and 2) 'If you have previously incorporated children's literature in your mathematics teaching, what enabled / encouraged you to do so?'.

An ethics clearance was sought and granted by the first author's institution in March 2016. A Teacher Information Sheet preceded the questionnaire and all respondents were provided with a brief overview of the study and assured that the data collected would be anonymized and stored securely.

\section{Data Analysis}

The open-ended questionnaire data was analysed thematically in two stages. Firstly, the first coder coded the two sets of data (perceived barriers and enablers) himself two weeks apart, and the intra-coder agreement percentages were equally high (98\% and 95.5\% respectively). The second coder subsequently coded around a third of each dataset. Due to the nature of the data (open-ended, non-binary), the inter-coder agreement percentage was calculated instead of the inter-coder reliability rate. The inter-coder agreement percentages for the perceived barriers and enablers were $95.6 \%$ and $91.5 \%$ respectively, highlighting that the coding frameworks that we have developed for this study's analysis were reliable (see Tables 2 and 3). That said, we 
fully acknowledge that the key drawback of reporting inter-coder agreement percentages is how agreement that could have happened by chance was not taken into account, so interpretations of our reported inter-coder agreement percentages must be treated with caution. Any disagreements in coding were subsequently discussed until both coders fully agreed with each other.

\section{Results}

\section{Characteristics of the survey participants}

Table 1 summarises key characteristics of the study's participants. In brief, of the 154 survey participants, 51 are in-service teachers and the remaining 103 participants are pre-service teachers. In each group, there are significantly more female teachers than there are male teachers, a common trend in the primary school sector in Ireland (Eurostat 2016). The participants came from all four provinces of Ireland, with the majority reported living in the eastern part of the country, specifically Leinster.. A roughly equal number of participants teach in each of the three key phases: JuniorSenior Infants Class (4-6 year olds), First-Third Class (6-9 year olds) and Fourth-Sixth Class (9-12 year olds). Nearly half of the in-service teachers in the study have less than 10 years of teaching experience.

When asked how frequently they have incorporated children's literature as part of their mathematics teaching in the current academic year, over $90 \%$ of them have either never used children's literature in their mathematics teaching or have done so, but very infrequently (i.e. 10 mathematics lessons or less). Only 9 in-service teachers $(17.6 \%)$ and 4 pre-service teachers (3.9\%) reported that they have used children's literature frequently in their mathematics teaching (i.e. 10+ lessons). Of these teachers, the majority of them ( 7 out of the 9 in-service teachers and 2 out of the 4 pre-service teachers) teach very young children (4-6 year olds). 
Table 1. Demographic characteristics of the survey participants.

\begin{tabular}{|c|c|c|c|}
\hline & $\begin{array}{c}\text { Total } \\
(N=154)\end{array}$ & $\begin{array}{c}\begin{array}{c}\text { In-service } \\
\text { teachers }\end{array} \\
(N=51)\end{array}$ & $\begin{array}{c}\text { Pre-service } \\
\text { teachers } \\
(N=103)\end{array}$ \\
\hline Characteristics & $\mathrm{n}(\%)$ & $\mathrm{n}(\%)$ & $\mathrm{n}(\%)$ \\
\hline \multicolumn{4}{|l|}{ Sex } \\
\hline Male & $17(11)$ & $6(11.8)$ & $11(10.7)$ \\
\hline Female & $137(89)$ & $45(88.2)$ & $92(89.3)$ \\
\hline \multicolumn{4}{|l|}{ Location } \\
\hline East (Leinster province including Dublin) & $110(71.4)$ & $29(56.9)$ & $81(78.6)$ \\
\hline South (Munster province) & $10(6.5)$ & $8(15.7)$ & $2(1.9)$ \\
\hline North (Ulster province) & $5(3.2)$ & $2(3.9)$ & $3(2.9)$ \\
\hline West (Connacht province) & $3(1.9)$ & $3(5.9)$ & $0(0)$ \\
\hline 'Ireland' / Not answered & $26(16.9)$ & $9(17.6)$ & $17(16.5)$ \\
\hline \multicolumn{4}{|l|}{ Class taught } \\
\hline Junior - Senior Infants Class (4-6 year olds) & $53(34.4)$ & $12(23.5)$ & $41(39.8)$ \\
\hline First - Third Class (6-9 year olds) & $48(31.2)$ & $16(31.4)$ & $32(31.1)$ \\
\hline Fourth - Sixth Class (9-12 year olds) & $46(29.9)$ & $19(37.3)$ & $27(26.2)$ \\
\hline A wide range of class levels / Not answered & $7(4.5)$ & $4(7.8)$ & $3(2.9)$ \\
\hline \multicolumn{4}{|l|}{ Teaching experience level (years) } \\
\hline $1-10$ & $\mathrm{n} / \mathrm{a}$ & $23(45)$ & $\mathrm{n} / \mathrm{a}$ \\
\hline $11-20$ & $\mathrm{n} / \mathrm{a}$ & $10(19.6)$ & $\mathrm{n} / \mathrm{a}$ \\
\hline $21-30$ & $\mathrm{n} / \mathrm{a}$ & $6(11.8)$ & $\mathrm{n} / \mathrm{a}$ \\
\hline$>30$ & $\mathrm{n} / \mathrm{a}$ & $7(13.7)$ & $\mathrm{n} / \mathrm{a}$ \\
\hline Not answered & $\mathrm{n} / \mathrm{a}$ & $5(9.8)$ & $\mathrm{n} / \mathrm{a}$ \\
\hline \multicolumn{4}{|l|}{$\begin{array}{l}\text { Frequency of using children's literature in } \\
\text { mathematics teaching within the current } \\
\text { academic year }\end{array}$} \\
\hline Never & $79(51.3)$ & $24(47.1)$ & $55(53.4)$ \\
\hline Infrequently (1-10 lessons) & $62(40.3)$ & $18(35.3)$ & $44(42.7)$ \\
\hline Frequently (>10 lessons) & $13(8.4)$ & $9(17.6)$ & $4(3.9)$ \\
\hline
\end{tabular}




\section{Key Findings}

\section{Perceived Barriers}

In brief, 151 of 154 teachers responded to the following survey question: 'In your experience, what are the key barriers that stop you from incorporating (more) children's literature in your mathematics teaching? These included teachers who reported having never incorporated children's literature in their mathematics teaching and those who have had some experience. Of these 151 teachers, 49 were in-service and 102 were pre-service teachers.

From the thematic coding analysis, thirteen perceived barriers were identified, which could be broadly grouped under five themes, namely Resource Constraint, Time Constraint, Lack of Pedagogical Knowledge and Confidence, Doubts about Outcome Expectancy, and Inhibiting Social Norms (see Table 2).

Table 2. Survey responses concerning perceived barriers to the integration of children's literature in mathematics teaching.

\begin{tabular}{|c|c|c|c|c|}
\hline Categories & Examples of statement & $\begin{array}{c}\text { Total } \\
(\mathrm{T}) \\
(N=151 / 154) \\
\end{array}$ & $\begin{array}{c}\text { In-service } \\
\text { teachers } \\
(\text { IST) } \\
(N=49 / 51) \\
\end{array}$ & $\begin{array}{c}\text { Pre-service } \\
\text { teachers } \\
(\text { PST) } \\
(N=102 / 103) \\
\end{array}$ \\
\hline & & $\begin{array}{c}f^{*} \\
(\%)\end{array}$ & $\begin{array}{c}f^{*} \\
(\%)\end{array}$ & $\begin{array}{c}f^{*} \\
(\%)\end{array}$ \\
\hline \multicolumn{5}{|c|}{ Theme 1: Resource Constraint (37.8\%) } \\
\hline $\begin{array}{l}\text { 1. Limited or lack of } \\
\text { (awareness of) } \\
\text { suitable children's } \\
\text { literature for specific } \\
\text { mathematical } \\
\text { concepts }\end{array}$ & $\begin{array}{l}\text { "Difficulty to find a story that } \\
\text { would work for a specific } \\
\text { topic" }\end{array}$ & $\begin{array}{c}38 \\
(22.8 \%)\end{array}$ & $\begin{array}{c}8 \\
(13.3 \%)\end{array}$ & $\begin{array}{c}30 \\
(28 \%)\end{array}$ \\
\hline $\begin{array}{l}\text { 2. Limited or lack of } \\
\text { suitable children's } \\
\text { literature at school }\end{array}$ & $\begin{array}{l}\text { "Lack of suitable literature in } \\
\text { school" }\end{array}$ & $\begin{array}{c}25 \\
(15 \%)\end{array}$ & $\begin{array}{c}15 \\
(25 \%)\end{array}$ & $\begin{array}{c}10 \\
(9.3 \%)\end{array}$ \\
\hline \multicolumn{5}{|c|}{ Theme 2: Time Constraint $(23.4 \%)$} \\
\hline $\begin{array}{l}\text { 3. Limited or lack of } \\
\text { time to use } \\
\text { children's literature }\end{array}$ & $\begin{array}{l}\text { "The time of a lesson, } \\
\text { reading a story book takes a } \\
\text { lot of time before actually } \\
\text { starting to get stuck into what }\end{array}$ & $\begin{array}{c}16 \\
(9.6 \%)\end{array}$ & $\begin{array}{c}11 \\
(18.3 \%)\end{array}$ & $\begin{array}{c}5 \\
(4.7 \%)\end{array}$ \\
\hline
\end{tabular}


during mathematics lessons

4. Limited or lack of time to search for suitable children's literature and plan for lessons

5. Limited or lack of time (unspecified) you want to have covered in the time allocated"

"Sometimes time consuming to find literature that links to topic!" and "Having to read each book through a maths lens in preparation"

"To be honest, it is a lot of effort to do so and teachers don't have much time to be doing it"

$\begin{array}{ccc}15 & 8 & 7 \\ (9 \%) & (13.3 \%) & (6.5 \%) \\ & & \\ & & 7 \\ 8 & 1 & (6.5 \%)\end{array}$

\begin{tabular}{|c|c|c|c|c|}
\hline \multicolumn{5}{|c|}{ Theme 3: Lack of Pedagogical Knowledge and Confidence (23.4\%) } \\
\hline 6. Limited or lack of & "I don't have enough & 27 & 8 & 19 \\
\hline $\begin{array}{l}\text { awareness / } \\
\text { experience in the } \\
\text { approach }\end{array}$ & $\begin{array}{l}\text { knowledge of how I can } \\
\text { incorporate the two subjects" }\end{array}$ & $(16.2 \%)$ & $(13.3 \%)$ & $(17.8 \%)$ \\
\hline $\begin{array}{l}\text { 7. Limited or lack of } \\
\text { training in the } \\
\text { approach }\end{array}$ & $\begin{array}{l}\text { "Not being trained properly } \\
\text { into how to incorporate them } \\
\text { into teaching Mathematics" }\end{array}$ & $\begin{array}{c}6 \\
(3.6 \%)\end{array}$ & $\begin{array}{c}1 \\
(1.7 \%)\end{array}$ & $\begin{array}{c}5 \\
(4.7 \%)\end{array}$ \\
\hline $\begin{array}{l}8 . \quad \text { Perceived } \\
\text { difficulty and/or fear } \\
\text { in implementing the } \\
\text { approach }\end{array}$ & $\begin{array}{l}\text { "Difficulty in thinking about } \\
\text { how to link story with maths, } \\
\text { and the different areas in } \\
\text { maths" }\end{array}$ & $\begin{array}{c}6 \\
(3.6 \%)\end{array}$ & $\begin{array}{c}0 \\
(0 \%)\end{array}$ & $\begin{array}{c}6 \\
(5.6 \%)\end{array}$ \\
\hline \multicolumn{5}{|c|}{ Theme 4: Doubts about Outcome Expectancy (14.4\%) } \\
\hline $\begin{array}{l}9 . \quad \text { Perceived } \\
\text { incompatibility } \\
\text { between children's } \\
\text { literature } \\
\text { mathematics and } \\
\text { teaching }\end{array}$ & $\begin{array}{l}\text { "I have always thought that } \\
\text { the two should be separate } \\
\text { subjects as literacy is based } \\
\text { on words and maths is the } \\
\text { opposite, based on numbers" }\end{array}$ & $\begin{array}{c}8 \\
(4.8 \%)\end{array}$ & $\begin{array}{c}2 \\
(3.3 \%)\end{array}$ & $\begin{array}{c}6 \\
(5.6 \%)\end{array}$ \\
\hline $\begin{array}{l}10 . \text { Perceived } \\
\text { limitation of the } \\
\text { approach in catering } \\
\text { for different learning } \\
\text { needs }\end{array}$ & $\begin{array}{l}\text { "Children with language } \\
\text { difficulties" }\end{array}$ & $\begin{array}{c}6 \\
(3.6 \%)\end{array}$ & $\begin{array}{c}2 \\
(3.3 \%)\end{array}$ & $\begin{array}{c}4 \\
(3.7 \%)\end{array}$ \\
\hline 11. Perceived & "Reading literature can cause & 5 & 1 & $\begin{array}{l}4 \\
(37 \%)\end{array}$ \\
\hline $\begin{array}{l}\text { ineffectiveness / } \\
\text { distraction of the } \\
\text { approach }\end{array}$ & & & & \\
\hline $\begin{array}{l}12 . \quad \text { Perceived } \\
\text { unsuitability of the } \\
\text { approach } \\
\text { children of certain } \\
\text { age groups }\end{array}$ & $\begin{array}{l}\text { "I teach 6th class. I have not } \\
\text { come across a book where } \\
\text { there is a sufficient challenge } \\
\text { for the children" }\end{array}$ & $\begin{array}{c}5 \\
(3 \%)\end{array}$ & $\begin{array}{c}3 \\
(5 \%)\end{array}$ & $\begin{array}{l}2 \\
(1.9 \%)\end{array}$ \\
\hline \multicolumn{5}{|c|}{ Theme 5: Inhibiting Social Norms (1.2\%) } \\
\hline $\begin{array}{l}\text { 13. Perceived } \\
\text { unwillingness of } \\
\text { class teachers / } \\
\text { mentors for the } \\
\text { approach to be } \\
\text { trialled }\end{array}$ & $\begin{array}{l}\text { "Unwillingness of class } \\
\text { teacher when on placement" }\end{array}$ & $\begin{array}{c}2 \\
(1.2 \%)\end{array}$ & $\begin{array}{c}0 \\
(0 \%)\end{array}$ & $\begin{array}{c}2 \\
(1.9 \%)\end{array}$ \\
\hline
\end{tabular}

* $f$ is here taken to refer to the number of teachers who mentioned a particular belief. Beliefs repeated by the same teacher were not counted twice. Participants were able to state more than one perceived barrier, explaining why the total number of $f(167)$ exceeded the total number of teachers who responded to this survey question (151). 
The first theme, Resource Constraint, was made up of only two categories, but they collectively accounted for $37.8 \%$ of all the coding on perceived barriers, making it the most predominant cluster of perceived barriers for teachers in Ireland.

Time Constraint and Lack of Pedagogical Knowledge and Confidence shared the second spot, with each theme accounting for $23.4 \%$ of all the coding on perceived barriers. Concerning the former, this theme was made up of three categories highlighting different ways in which limited or lack of time could prohibit teachers from incorporating children's literature into their mathematics teaching. The first of these categories was Limited or lack of time to use children's literature during mathematics lessons $(9.6 \%)$, as explained by the pressure of having to cover all mathematical concepts in crowded curriculum, and having to teach multi-grade class in some cases. The second of these categories was Limited or lack of time to search for suitable children's literature and plan for lessons $(9 \%)$ where cited examples include having to find time to read chosen children's literature through a mathematical lens before the lesson. For responses that simply stated, for example, "Don't have time" without specifying in what way, these were coded as Limited or lack of time (unspecified) $(4.8 \%)$.

As previously noted, Lack of Pedagogical Knowledge and Confidence shared the second place with Time Constraints, and this theme was made up of three barriers that are thought to prevent teachers from incorporating children's literature in their mathematics teaching. These barriers were: Limited or lack of awareness / experience in the approach (16.2\%) where several teachers admitted not knowing that children's 
literature can be integrated into mathematics teaching; Limited or lack of training in the approach $(3.6 \%)$ where some teachers attributed lack of training (either in-service or pre-service training) as a key barrier, and; Perceived difficulty and/or fear in implementing the approach (3.6\%) where lack of confidence appeared to have prevented some teachers from incorporating children's literature in their mathematics teaching.

The next theme, Doubts about Outcome Expectancy (14.4\%), was concerned with teachers' perceptions that question the effectiveness and suitability of the approach. The theme was made up of four types of doubts i.e. Perceived incompatibility between children's literature and mathematics teaching (4.8\%) where some teachers strongly believed in the separation of mathematics and literacy as two separate subjects; Perceived limitation of the approach in catering for different learning needs (3.6\%) where some teachers cited how the use of children's literature in mathematics teaching and learning could be problematic for some children, for example, children with language difficulties; Perceived ineffectiveness / distraction of the approach (3\%) where some teachers cited how the use of children's literature in Mathematics lessons could distract children from mathematics learning, and; Perceived unsuitability of the approach for children of certain age groups (3\%) where some teachers perceived the use of children's literature in mathematics teaching to be suitable for only very young children, but not for older ones.

The final theme, Inhibiting Social Norms, accounted for only $1.2 \%$ of all the coding on perceived barriers, but its presence was a useful contrast to Enabling Social Norms, one of the Perceived Enablers themes to be discussed in the following section. The one category that made up the Inhibiting Social Norms theme was Perceived unwillingness of class teachers / mentors for the approach to be trialled (1.2\%) where 
some teachers, particularly pre-service teachers, cited how their attempts to incorporate children's literature in their mathematics teaching were not received positively by their class teacher or mentor.

It is worth noting that the five most-cited categories alone accounted for over $70 \%$ of all the coding on perceived barriers, and these categories were: Limited or lack of (awareness of) suitable children's literature for specific mathematical concepts (22.8\%); Limited or lack of awareness / experience in the approach (16.2\%); Limited or lack of suitable children's literature at school (15\%); Limited or lack of time to use children's literature during mathematics lessons (9.6\%), and; Limited or lack of time to search for suitable children's literature and plan for lessons (9\%). Ways to address each of these key perceived barriers will be discussed in the following section.

Interestingly, four of these five most-cited perceived barriers were also where the biggest differences between pre- and in-service teachers' perceptions were evident. For example, more in-service teachers $(25 \%)$ proportionally cited the Limited or lack of suitable children's literature at school category when compared with pre-service teachers $(9.3 \%)$. The opposite was true for the Limited or lack of (awareness of) suitable children's literature for specific mathematical concepts category where more pre-service teachers $(28 \%)$ proportionally cited this barrier when compared with their in-service counterparts (13.3\%). Finally, in-service teachers appeared to be more sensitive to time constraints whereby more of them proportionally cited Limited or lack of time to use children's literature during mathematics lessons (18.3\%) and Limited or lack of time to search for suitable children's literature and plan for lessons (13.3\%) as key barriers when compared with their pre-service counterparts $(4.7 \%$ and $6.5 \%$ respectively). 


\section{Perceived Enablers}

All 75 participants (48.7\%), whom reported having incorporated children's literature in their mathematics teaching either frequently or infrequently, responded to the survey question 'If you have previously incorporated children's literature in your mathematics teaching, what enabled / encouraged you to do so?'. Of these participants, 27 were inservice and 48 were pre-service teachers.

From the thematic coding analysis, twelve perceived enablers were identified, which could be broadly grouped into three themes, namely Perceived Pedagogical Benefits, Enabling Social Norms, and Love of Children's Literature (see Table 3).

Table 3. Survey responses concerning perceived enablers to the integration of children's literature in mathematics teaching.

\begin{tabular}{|c|c|c|c|c|}
\hline Categories & Examples of statement & $\begin{array}{c}\begin{array}{c}\text { Total } \\
(\mathrm{T})\end{array} \\
(N=75 / 154) \\
\end{array}$ & $\begin{array}{c}\text { In-service } \\
\text { teachers } \\
(\text { IST }) \\
(N=27 / 51) \\
\end{array}$ & $\begin{array}{c}\begin{array}{c}\text { Pre-service } \\
\text { teachers } \\
(\text { PST })\end{array} \\
(N=48 / 103) \\
\end{array}$ \\
\hline & & $\begin{array}{c}f^{*} \\
(\%)\end{array}$ & $\begin{array}{c}f^{*} \\
(\%)\end{array}$ & $\begin{array}{c}f^{*} \\
(\%)\end{array}$ \\
\hline \multicolumn{5}{|c|}{ Theme 1: Perceived Pedagogical Benefits (69.2\%) } \\
\hline $\begin{array}{l}\text { 1. Encouraged and } \\
\text { inspired by teacher's } \\
\text { own perception that } \\
\text { teaching mathematics } \\
\text { through children's } \\
\text { literature makes the } \\
\text { teaching more } \\
\text { engaging and fun }\end{array}$ & $\begin{array}{l}\text { "To help to engage the } \\
\text { children in the maths } \\
\text { topic being thought. [...] } \\
\text { Young children enjoy } \\
\text { stories and books and } \\
\text { thought it would be } \\
\text { useful to get them } \\
\text { interested in the topic" }\end{array}$ & $\begin{array}{c}24 \\
(25.5 \%)\end{array}$ & $\begin{array}{c}8 \\
(22.9 \%)\end{array}$ & $\begin{array}{c}16 \\
(27.1 \%)\end{array}$ \\
\hline $\begin{array}{l}\text { 2. Encouraged and } \\
\text { inspired by teacher's } \\
\text { own belief in the } \\
\text { value of cross- } \\
\text { curricular teaching }\end{array}$ & $\begin{array}{l}\text { "Don't like subject } \\
\text { divides - I want learning } \\
\text { to be without subject } \\
\text { boundaries" }\end{array}$ & $\begin{array}{c}11 \\
(11.7 \%)\end{array}$ & $\begin{array}{c}8 \\
(22.9 \%)\end{array}$ & $\begin{array}{c}3 \\
(5.1 \%)\end{array}$ \\
\hline $\begin{array}{l}\text { 3. Encouraged and } \\
\text { inspired by teacher's } \\
\text { own perception that } \\
\text { teaching mathematics } \\
\text { through children's } \\
\text { literature helps } \\
\text { children to make } \\
\text { meaningful } \\
\text { connections between } \\
\text { their mathematics }\end{array}$ & $\begin{array}{l}\text { "To help them to see that } \\
\text { the maths that they were } \\
\text { doing is linked with real } \\
\text { life situations and not just } \\
\text { to be done from work } \\
\text { books" }\end{array}$ & $\begin{array}{c}11 \\
(11.7 \%)\end{array}$ & $\begin{array}{c}5 \\
(14.3 \%)\end{array}$ & $\begin{array}{c}6 \\
(10.2 \%)\end{array}$ \\
\hline
\end{tabular}


learning and their everyday life

4. Encouraged and inspired by teacher's desire to try new methods of teaching mathematics

5. Encouraged and inspired by teacher's own perception that teaching mathematics through children's literature helps children to visualize mathematical

concepts

6. Encouraged and inspired by teacher's own perception that teaching mathematics through children's literature helps children to be better in solving word problems

7. Encouraged and inspired by teacher's own perception that teaching mathematics through children's literature helps children recall what they have learned

8. Encouraged and inspired by teacher's own perception that

"Allows inclusion of 9 6

"To use other forms for $(9.6 \%)$ 3 teaching, so that the children are learning and revising without even knowing it"

"Visuals/pictures allow children to visualise concepts"

$\begin{array}{ccc}4 & 2 & 2 \\ (4.3 \%) & (5.7 \%) & (3.4 \%)\end{array}$

"Attempting to engage young children in problem-solving"

3

$(3.2 \%)$

1

$(2.9 \%)$

2

"Aids recall"

2

$(2.1 \%) \quad(2.9 \%)$

1

$(1.7 \%)$ $\begin{array}{ccc}1 & 0 & 1 \\ (1.1 \%) & (0 \%) & (1.7 \%)\end{array}$

teaching mathematics through children's literature makes learning more inclusive

\begin{tabular}{|c|c|c|c|c|}
\hline \multicolumn{5}{|c|}{ Theme 2: Enabling Social Norms (27.7\%) } \\
\hline $\begin{array}{l}\text { 9. Encouraged and } \\
\text { inspired by training }\end{array}$ & $\begin{array}{l}\text { "We were encouraged to } \\
\text { do so by lecturers at } \\
\text { college" }\end{array}$ & $\begin{array}{c}20 \\
(21.3 \%)\end{array}$ & $\begin{array}{c}4 \\
(11.4 \%)\end{array}$ & $\begin{array}{c}16 \\
(27.1 \%)\end{array}$ \\
\hline $\begin{array}{l}\text { 10. Encouraged and } \\
\text { inspired by mentor / } \\
\text { other colleagues }\end{array}$ & $\begin{array}{l}\text { "From speaking to other } \\
\text { teachers, I was advised } \\
\text { this was a great way to } \\
\text { start a topic in maths" }\end{array}$ & $\begin{array}{c}4 \\
(4.3 \%)\end{array}$ & $\begin{array}{c}0 \\
(0 \%)\end{array}$ & $\begin{array}{c}4 \\
(6.8 \%)\end{array}$ \\
\hline $\begin{array}{l}\text { 11. Encouraged and } \\
\text { inspired by on-line } \\
\text { resources }\end{array}$ & $\begin{array}{l}\text { "I saw an idea for a } \\
\text { Maths lesson using } \\
\text { children's literature } \\
\text { online" }\end{array}$ & $\begin{array}{c}2 \\
(2.1 \%)\end{array}$ & $\begin{array}{c}0 \\
(0 \%)\end{array}$ & $\begin{array}{c}2 \\
(3.4 \%)\end{array}$ \\
\hline \multicolumn{5}{|c|}{ Theme 3: Love of Children's Literature (3.2\%) } \\
\hline $\begin{array}{l}\text { 12. Encouraged and } \\
\text { inspired by teacher's } \\
\text { own love of } \\
\text { children's literature }\end{array}$ & $\begin{array}{l}\text { "I love books and reading } \\
\text { to the children" }\end{array}$ & $\begin{array}{c}3 \\
(3.2 \%)\end{array}$ & $\begin{array}{c}3 \\
(8.6 \%)\end{array}$ & $\begin{array}{c}0 \\
(0 \%)\end{array}$ \\
\hline & & 94 & 35 & 59 \\
\hline
\end{tabular}


* $f$ is here taken to refer to the number of teachers who mentioned a particular belief. Beliefs repeated by the same teacher were not counted twice. Participants were able to state more than one perceived enabler, explaining why the total number of $f(94)$ exceeded the total number of teachers who responded to this survey question (75).

The first theme, Perceived Pedagogical Benefits, was made up of eight categories, and they collectively accounted for $69.2 \%$ of all the coding on perceived enablers, making it the most predominant cluster of perceived enablers for teachers in Ireland. To avoid any unnecessary repetition here, these eight categories can be found in Table 3. Of particular importance were the top three categories which collectively accounted for over $50 \%$ of all the coding on perceived enablers.

The second theme, Enabling Social Norms, accounted for $27.7 \%$ of all the coding on perceived enablers. This theme was made up of three perceived enablers that were concerned with being encouraged and inspired by others, specifically by training (21.3\%), by mentor or colleagues $(4.3 \%)$, and by relevant on-line resources that they came across, for example, recommended stories for mathematics teaching and learning (2.1\%). Finally, feeling encouraged and inspired by teacher's own love of children's literature made up the third and final theme, Love of Children's Literature, accounting for $3.2 \%$ of all the coding on perceived enablers.

It is worth noting that the five most-cited categories accounted for nearly $80 \%$ of all the coding on perceived enablers, and these categories were: Encouraged and inspired by teacher's own perception that teaching mathematics through children's literature makes the teaching more engaging and fun (25.5\%); Encouraged and inspired by training (21.3\%); Encouraged and inspired by teacher's own belief in the value of cross-curricular teaching (11.7\%); Encouraged and inspired by teacher's own perception that teaching mathematics through children's literature helps children to make meaningful connections between their mathematics learning and their everyday 
life (11.7\%), and; Encouraged and inspired by teacher's desire to try new methods of teaching mathematics $(9.6 \%)$. It is also worth highlighting that apart from the Encouraged and inspired by training category, the remaining four categories all belonged to the Perceived Pedagogical Benefits theme, further highlighting the predominance of this theme overall.

Proportionally, most perceived enablers were cited equally by in- and preservice teachers. Exceptions were the Encouraged and inspired by teacher's own belief in the value of cross-curricular teaching category where nearly a quarter of in-service teachers cited this, compared to just $5.1 \%$ of pre-service teachers. Finally, more preservice teachers $(37.3 \%)$ proportionally appeared to be encouraged and inspired by the three perceived enablers under the Enabling Social Norms theme when compared to their in-service counterparts $(11.4 \%)$.

\section{Discussion and conclusion}

This study is part of an international effort with a research mandate to explore factors that support or negate the integration of children's literature in mathematics teaching and learning from the viewpoint of teachers. This paper reported the perspectives of inand pre-service teachers of children aged 4 to 12 years old in Ireland only. The comparative analysis of findings from different countries within the study will be reported in a separate paper.

The contextual data of the teachers in this study indicated that over $90 \%$ of them have either never used children's literature in their mathematics teaching or have done so, but very infrequently. Given that empirical international studies over the past decades (van den Heuvel-Panhuizen, Elia, and Robitzsch 2016; Hong 1996) have shown pedagogical benefits of using children's literature to help children learn mathematics 
more effectively, this figure is concerning. The findings of the current study provided some insights into what these teachers perceived to be some of the key barriers that prohibit them from incorporating children's literature in their mathematics teaching, and what they perceived to be some of the key enablers that would make incorporation possible. The following discussions of the current study's findings will be framed using Ajzen's (1991) seminal work on the Theory of Planned Behavior (TPB) model.

\section{Perceived barriers}

Thirteen perceived barriers emerged from the coding analysis, and were grouped under five themes, namely Resource Constraint, Time Constraint, Lack of Pedagogical Knowledge and Confidence, Doubts about Outcome Expectancy, and Inhibiting Social Norms. Interestingly, these themes could be mapped meaningfully onto Ajzen's (1991) TPB model (see Figure 1).

Figure 1. Perceived barrier themes mapped onto the Theory of Planned Behavior model

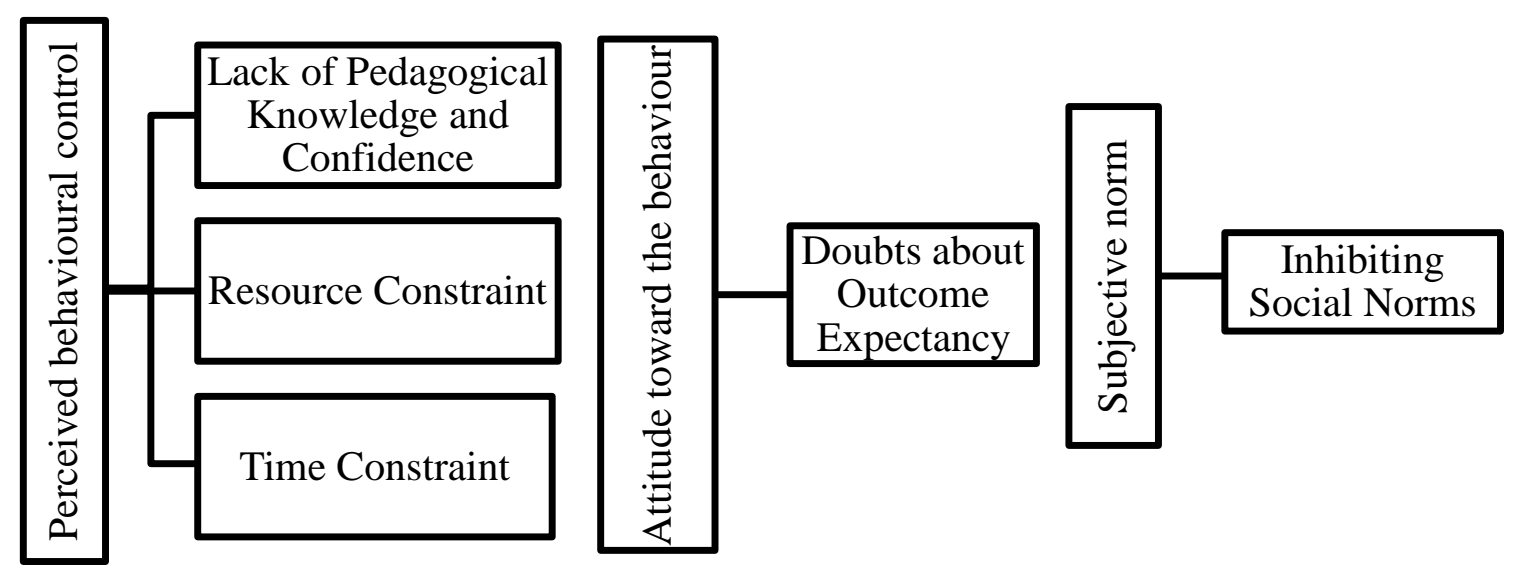

The first three themes can be mapped onto the Perceived behavioural control component of the TPB model which is concerned with the extent to which a behaviour 
is considered easy or difficult as well as any anticipated impediments and obstacles. There were three perceived barriers under the Lack of Pedagogical Knowledge and Confidence theme, two under the Resource Constraint theme, and the three under the Time Constraint theme. These barriers highlight how some perceived the use of children's literature in mathematics learning as daunting, largely due to expressed impediments and limitations such as a lack of training.

The fourth theme, Doubts about Outcome Expectancy, can be mapped onto the Attitude toward the behaviour component of the TPB model which is the extent to which a person has a positive or negative viewpoint of the behaviour in question. The four perceived barriers under this theme indicated doubts about the effectiveness of using children's literature in mathematics teaching.

The fifth and final theme, Inhibiting Social Norms, can be mapped onto the Subjective norm component of the TPB model which is concerned with the level of social pressure for one to enact or not enact a particular behaviour. The only perceived barrier cited under this theme indicated a concern that teacher' mentors would not approve of the use of children's literature in mathematics teaching.

Under the five themes found in the current study and mapped onto Ajzen's (1991) TPB model there were 13 perceived barriers, of which five accounted for over $70 \%$ of all the coding on perceived barriers. The implications of these barriers will be discussed below. The perceived barrier in relation to Limited or lack of (awareness of) suitable children's literature for specific mathematical concepts can be better understood by examining MathsThroughStories.org, which is a large database of recommendations for mathematical stories. Whilst not aiming to be an exhaustive listing of mathematical related stories, it has over 30 picture books that can be used in the teaching of 
multiplication while percentages and negative numbers only have one example each. This suggests that there is a dearth of age-appropriate and content specific books that needs to be filled if teachers are to be encouraged to successfully use children's literature in their mathematics teaching. That said, it could also be the case that teachers may not be aware of the range of literature without an explicit mathematical content but which could potentially be used to contextualise mathematical concepts. In which case, pre- and in-service teacher educators need to do more to raise awareness by introducing these teachers to resources, and articles written by practitioners sharing their experience of teaching mathematics using children's literature.

In relation to the second perceived barrier, Limited or lack of suitable children's literature at school, it can be argued that this perceived barrier can be addressed by following the advice of Schiro (1997) and Wilburne, Keat, and Napoli (2011) whereby potential opportunities for mathematics teaching can be found in almost any book provided that teachers put on a mathematical lens. CPD to help teachers identify mathematics teaching opportunities in any children's book would help to address this second perceived barrier.

Concerning Limited or lack of time to use children's literature during mathematics lessons, this perceived barrier highlighted a missed opportunity for crosscurricular learning. As Altieri (2010) argues, when connections between mathematics and literacy are created, children's mathematics and literacy skills can be developed in a time-efficient manner. This resonates with the recommendations of the Literacy and Numeracy Strategy which notes that more needs to be done to support the development of children's literacy and numeracy skills in all curriculum subjects (DES 2011).

In relation to Limited or lack of time to search for suitable children's literature and plan for lessons, this is an area which initiatives, such as MathsThroughStories.org 
aims to address by helping to make the process of planning for and locating relevant children's literature a more time-efficient process for practitioners. Other possibilities could include drawing on the professional expertise of librarians in education and public library settings to support the development and curation of thematic and age appropriate children's literature collections searchable using library standard discovery tools.

The fifth and final most-cited perceived barrier, Limited or lack of awareness / experience in the approach, highlighted that more needs to be done as part of ITE and CPD training programmes to raise awareness of the possibility of teaching mathematics using children's literature. This concurs with the research carried out by Wilburne and Napoli (2008) who determined that ITE providers need to embed more literature-based mathematics experiences into their programmes.

\section{Perceived enablers}

As previously noted, twelve perceived enablers emerged from the coding analysis, and were grouped under three themes, namely Perceived Pedagogical Benefits, Enabling Social Norms, and Love of Children's Literature. These themes could also be meaningfully mapped onto Ajzen’s (1991) TPB model (see Figure 2). 
Figure 2. Perceived enabler themes mapped onto the Theory of Planned Behavior model

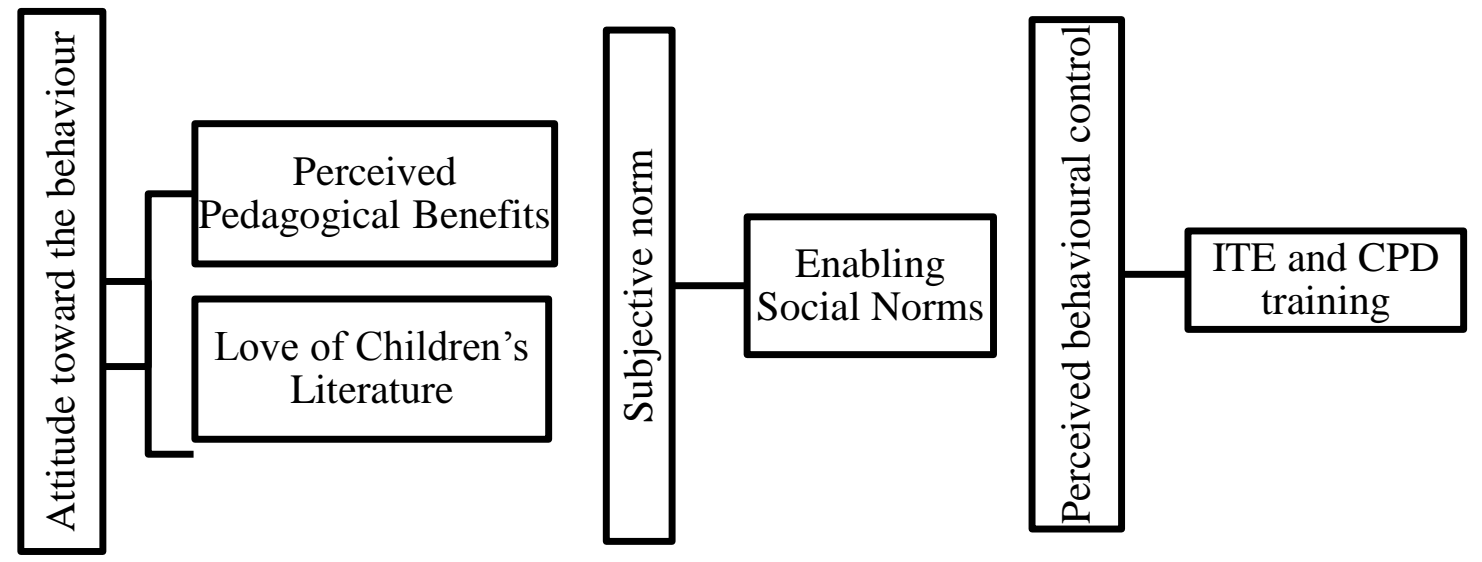

Specifically, the first and third themes can be mapped onto the Attitude toward the behaviour component of the TPB model. The eight perceived enablers under the Perceived Pedagogical Benefits theme and the one perceived enabler under the Love of Children's Literature theme suggested a range of favourable views relating to the use of children's literature in mathematics teaching.

The second theme, Enabling Social Norms, can be mapped onto the Subjective norm component of the TPB model. The three perceived enablers under this theme highlighted a range of sources where social encouragement can be found, and they are pre- and in-service teacher trainers; mentors and colleagues; and on-line resources.

To an extent, it can also be argued that the training teachers receive and the support and ideas they find on-line can be mapped onto the Perceived behavioural control component of the TPB model. As some teachers in this study have already received some training and located useful tips and ideas from on-line sources on how children's literature can be incorporated into their mathematics instruction, they would not find its integration as daunting or difficult as other teachers who have never received either the training or come across on-line resources before. 
Beyond mapping the five themes as found in the current study onto Ajzen's (1991) TPB model, the five most-cited perceived enablers, which collectively accounted for over $80 \%$ of all the coding on perceived enablers, and their implications will be discussed below.

It is worth highlighting that four of these five perceived enablers all belong to the Perceived Pedagogical Benefits theme, signifying the key importance of this perceived enabler. Specifically, the majority of teachers who had some experience in using children's literature in their mathematics teaching reported that they used children's literature because they believed that it would make their mathematics teaching more engaging and fun as well as more relatable to children's everyday life. This finding reinforces the recommendations of the Literacy and Numeracy Strategy that ITE and CPD for teachers focus on how best to support children in applying mathematical concepts in real-life settings and the ability "to infuse language, thought and meaning into mathematics teaching" (DES 2011, 31). They also reported using children's literature due to their own belief in the value of cross-curricular teaching and their own desire to try new methods of teaching mathematics. The predominance of this theme arguably suggests that the more teachers are made aware, as part of their training, of potential pedagogical benefits that come with using children's literature in their mathematics instruction, the more likely it is that they will consider using it.

Finally, the importance of being exposed to using children's literature in mathematics teaching as part of pre- and in-service teacher training cannot be underestimated as almost a quarter of all coding on perceived enablers are related to the Encouraged and inspired by training category. Again this corresponds with the work of Wilburne and Napoli (2008) and national recommendations that "Greater direction and 
guidance should be provided for teachers to enable them to extend their repertoire of teaching approaches and methods (NCCA 2005, 10)

\section{Limitations and significance of the study}

Whilst the study has given some insights into the perceived barriers and enablers to integrating children's literature, it is important to highlight its limitations. Teachers' opinions were gathered using a mixture of dichotomous and open-ended questions. While such methods gathered much data, they did not allow the opportunity for the researcher to probe participants on certain responses and further investigate specific themes as they emerged from the data. It is also acknowledged that in this study we have solely relied on teachers' perspectives and have not attempted to garner the views of other stakeholders, such as students and parents/guardians.

However despite its inherent limitations, the significance of this study is twofold. From the theoretical perspective, the current study adopted Ajzen's (1991) TPB model to help make sense of teachers' perceived barriers to and enablers for the integration of children's literature in mathematical teaching under the five themes identified. From the practical perspective, the study highlighted a wide range of perceived barriers, and suggested realistic strategies to address these. Similarly, the study also helped to identify several perceived enablers that teachers in the study have found useful in encouraging them to incorporate children's literature in their mathematics pedagogy. .

Perhaps the next phase of the study should involve developing a numeracy themed bibliography of children's literature that is of literary and aesthetic merit and allows for progression in deepening children's learning. This initiative would have to happen alongside professional development in the use of such literature so as to address perceived barriers and enhance the existing enablers reported in this study, thereby 
supporting the meaningful integration of children's literature in mathematics teaching and learning.

\section{Acknowledgments}

The authors would also like to thank all the teachers who contributed to the study.

\section{References}

Ajzen, Icek. 1991. "The theory of planned behavior." Organizational behavior and human decision processes 50 (2):179-211.

Altieri, Jennifer L. 2010. Literacy+ Math: Liturgical Press.

Bintz, William P, Sara D Moore, Pam Wright, and Lyndsie Dempsey. 2011. "Using literature to teach measurement." The Reading Teacher 65 (1):58-70.

Casey, Beth, Sumru Erkut, Ineke Ceder, and Jessica Mercer Young. 2008. "Use of a storytelling context to improve girls' and boys' geometry skills in kindergarten." Journal of Applied Developmental Psychology 29 (1):29-48.

Cotti, Rainy, and Michael Schiro. 2004. "Connecting teacher beliefs to the use of children's literature in the teaching of mathematics." Journal of Mathematics Teacher Education 7 (4):329-56.

DES. 1999. "Primary School Mathematics Curriculum." In. Dublin, The Stationary Office: Department of Education and Skills.

DES. 2011. "Literacy and Numeracy for Learning and Life: The National Strategy to Improve Literacy and Numeracy among Children and Young People (20112020)." In. Dublin: Department of Education and Skills.

Eurostat. 2016. "Women teachers largely over-represented in primary education in the EU. ." In. Eurostat Press Office.

Feiman-Nemser, Sharon. 1989. "Teacher Preparation: Structural and Conceptual Alternatives. Issue Paper 89-5."

Handal, Boris, and Anthony Herrington. 2003. "Mathematics teachers' beliefs and curriculum reform." Mathematics education research journal 15 (1):59-69.

Hong, Haekyung. 1996. "Effects of mathematics learning through children's literature on math achievement and dispositional outcomes." Early Childhood Research Quarterly 11 (4):477-94.

Jennings, Clara M, James E Jennings, Joyce Richey, and Lisbeth Dixon-Krauss. 1992. "Increasing interest and achievement in mathematics through children's literature." Early Childhood Research Quarterly 7 (2):263-76.

Kennedy, Mary M. 1991. "An Agenda for Research on Teacher Learning. NCRTL Special Report."

Krick-Morales, Brenda. 2006. "Reading and understanding written math problems." Retrieved on August 3:2012.

Kurz, Terri L, and Barbara Bartholomew. 2012. "Supporting Math Skills with Children's Stories." Kappa Delta Pi Record 48 (4):184-8.

Liljedahl, Peter. 2015. "Numeracy task design: A case of changing mathematics teaching practice." ZDM 47 (4):625-37.

Lortie, Dan. 1975. "School teacher: A sociological perspective." Chicago: University of Chicago. 
Manouchehri, Azita, and Terry Goodman. 1998. "Mathematics curriculum reform and teachers: Understanding the connections." The Journal of Educational Research $92(1): 27-41$.

McAndrew, Erica M, Wendy L Morris, and Francis Skip Fennell. 2017. "GeometryRelated Children's Literature Improves the Geometry Achievement and Attitudes of Second-Grade Students." School Science and Mathematics 117 (12):34-51.

Moyer, Patricia S. 2000. "Communicating mathematically: Children's literature as a natural connection." The Reading Teacher 54 (3):246-55.

NCCA. 2005. "Primary School Curriculum Review Phase 1 Final Report." In. Dublin: National Council for Curriculum and Assessment.

NCCA. 2014. "Mathematics in Early Childhood and Primary Education (3 - 8 years)." Research Report No. 18. In. Dublin: National Council for Curriculum and Assessment.

NCCA. 2016. "Background Paper and Brief for the development of a new Primary Mathematics Curriculum." In. Dublin: National Council for Curriculum and Assessment.

NCTM. 2000. "Principles and Standards for School Mathematics." In. Reston, VA: National Council of Teachers of Mathematics.

Pierce, Robyn, and Lynda Ball. 2009. "Perceptions that may affect teachers' intention to use technology in secondary mathematics classes." Educational Studies in Mathematics 71 (3):299-317.

Prendergast, Mark, and Paraic Treacy. 2018. "Curriculum reform in Irish secondary schools-a focus on algebra." Journal of Curriculum Studies 50 (1):126-143.

Schiro, Michael. 1997. Integrating Children's Literature and Mathematics in the Classroom: Children as Meaning Makers, Problem Solvers, and Literary Critics: ERIC.

Shatzer, Joyce. 2008. "Picture book power: Connecting children's literature and mathematics." The Reading Teacher 61 (8):649-53.

Trakulphadetkrai, Natthapoj Vincent, Louise Courtney, Jon Clenton, Jeanine TreffersDaller, and Anna Tsakalaki. 2017. "The contribution of general language ability, reading comprehension and working memory to mathematics achievement among children with English as additional language (EAL): an exploratory study." International Journal of Bilingual Education and Bilingualism:1-15.

Underwood, Paul R. 2012. "Teacher beliefs and intentions regarding the instruction of English grammar under national curriculum reforms: A Theory of Planned Behaviour perspective." Teaching and Teacher education 28 (6):911-25.

Van den Heuvel-Panhuizen, Marja, and Iliada Elia. 2011. "Kindergartners' performance in length measurement and the effect of picture book reading." ZDM 43 (5):621-35.

van den Heuvel-Panhuizen, Marja, Iliada Elia, and Alexander Robitzsch. 2016. "Effects of reading picture books on kindergartners' mathematics performance." Educational Psychology 36 (2):323-46.

Whitin, David Jackman. 1992. Read Any Good Math Lately?: Children's Books for Mathematical Learning, K-6: Heinemann Educational Books.

Whittin, DJ, and Sandra Wilde. 1992. "Read Any Good Math Lately? Children's Books for Mathematical Learning, K-6." In.: Portsmouth, NH: Heinemann Educational Books. 
Wilburne, Jane M, Jane B Keat, and Mary P Napoli. 2011. Cowboys Count, Monkeys Measure, and Princesses Problem Solve: Building Early Math Skills through Storybooks: ERIC.

Wilburne, Jane M, and Mary Napoli. 2008. "Connecting Mathematics and Literature: An Analysis of Pre-Service Elementary School Teachers' Changing Beliefs and Knowledge." Issues in the Undergraduate Mathematics Preparation of School Teachers 2.

Wittrock, Merlin C, Christopher M Clark, and Penelope L Peterson. 1990. Students' thought processes. Vol. 3: Macmillan Pub Co. 